\title{
Human Resources Accounting: Issues, Benefits and Challenges
}

\section{Osemeke Monday}

Department of Business Administration, College of Management and Social Sciences, Samuel Adegboyega University, Ogwa, Nigeria

Email address:

mosemeke@sau.edu.ng, osemeke2k2002@yahoo.com

\section{To cite this article:}

Osemeke Monday. Human Resources Accounting: Issues, Benefits and Challenges. International Journal of Economics, Finance and Management Sciences. Vol. 5, No. 3, 2017, pp. 129-138. doi: 10.11648/j.ijefm.20170503.11

Received: September 21, 2016; Accepted: January 14, 2017; Published: April 2, 2017

\begin{abstract}
The focus of this paper is on Human Resources Accounting which has not been properly integrated into the financial statement of various organizations and being regarded as assets. The main purpose of this study is to examine the issues involved in valuing human resource /people working in organizations, which has been regarded as the most valuable assets in business organizations, the benefits of attaching values and the challenges and obstacles of implementing the Human Resource accounting disclosures of such values in the firm's statement of financial position. In the pursuit of the focus of this study the paper adopts exploratory and content analysis methods of secondary data. The paper reveals that the exponent of human resources valuation models in most cases have not dealt with the mode of recording and disclosure of the accounting information relating to human resources in the books of account or financial statements of the organization. In most cases, the human resource accounting information is given in the form of supplementary information attached to the financial statements. This is of great concern to accounting professionals and practitioners. The paper concludes that considerable research done is due to the increasing importance of human capital in the economy to develop the concepts and methods of valuing human resource that has been recognized as human resources accounting (HRA), and that there is a great need for evolving a system of accounting for human resource that is acceptable to professional accountants, mangers and other decision makers - investors, creditors and other stakeholders.
\end{abstract}

Keywords: Human Resources (HR), Human Resources Accounting (HRA), Challenges

\section{Introduction}

The global economy has been shifting from an industrial economy to an information-based economy as a result of the Internet and other new technologies. Therefore, human capital has become a greater benefit to companies than ever before. Other intangible assets can be accounted for with reasonable accuracy. Despite being much more complex than other intangible assets, it is still important that people in the accounting profession seek a method of accounting for human capital. Doing so would represent arguably the most monumental finding in the history of financial accounting, but until a reliable measure to report human capital is established, the Financial Accounting Standards Board cannot issue mandate that companies should report that valuable information. Such an action so would only produce inaccurate information leading to misguided decisions (Stanko, Zeller, \& Melena, 2014).
The considerable research done is due to the increasing importance of human capital in the economy to develop the concepts and methods of valuing human resource that has been recognized as human resources accounting (HRA) (Flamholtz, 1987). Hence, there is a great need for evolving a system of accounting for human resource that is acceptable to professional accountants, mangers and other decision makers - investors, creditors and other stakeholders (Ratti, 2012).

Human resources accounting strives to quantify the intangible qualities that individuals bring to a business. While long recognized as a business asset, human capital has historically proven problematic for accountants and economists to evaluate. A clearer understanding of this area of accounting is necessary as businesses become increasingly dependent on the knowledge and capabilities of employees in the information age.

However, there have been controversial issues of human capital reporting on whether its value is relevant to be 
considered as an asset, even though its association with company's expected future benefits is not certain. Some group considered it as what people owned from learning, experience and skill while another group delineated it as human capability that is directly linked to the work of (Maani \& Jeradat, 2010, cited in Micah et al, 2012). Few other studies on value relevance of intellectual (human) capital assets include; Okwy and Christopher (2010).

Consequently, the purpose of this study is to examine the issues involved in valuing human resource /people working in organizations, which has been regarded as the most valuable assets in business organizations, the benefits of attaching values and the challenges and obstacles of implementing the Human Resource accounting disclosures of such values in the firm's statement of financial position.

\section{Literature Review}

\subsection{Concepts of HRA}

The American Accounting Association (1973) defined Human Resource Accounting as the process of identifying, measuring and communicating information about human resources in order to facilitate effective management within an organization. This definition considers HRA as the process of recognition and the quantification of human resources for the purpose of assisting the effective management of an organization. It also recognizes the measurement of data related to placement, training and development of employees and involves in the evaluation of financial condition of people in an organization. The definition is however unfinished as it is not specific as to what constitute the human resources expenditure and how it is to be recognized.

Friedman and Lev (1974) and Lau and Lau (1978) consider HRA as a method for systematically measuring both the asset value of labour and the amount of asset creation that can be attributed to personnel activities. Considering the contribution aspect of human resources this definition incorporates the economic benefit attributable to the human resources in addition to recognizing their cost implication.

Gupta (1991) defined the HRA as basically an information system that tells management what changes are occurring overtime to the human resources of the business. It involves accounting for investment in people and their replacement costs, and also the economic value of people in an organization. Therefore, HRA provides a comprehensive look at one method of using human resource cost and value information in the decision-making process.

Newman (1999) defined, HRA as the measurement of the abilities of all employees of a company, at every level management, supervisory and ordinary employees - to produce value from their knowledge and the capabilities of their minds. He considered the current growth in the service industry where the knowledge and intellectual capabilities of employees are the key for success. Here, HRA is seen as the wealth of the employees' knowledge and intellectual capabilities added to the organization thereby making it to earn profit that result in success.

Jasrotia (2004), in her definition, also views HRA as a measurement and reporting of the cost and value of people as organizational resources. The uniqueness of this definition is on the reporting aspect of the HRA. This definition rests on the premise that knowledge and intellectual capabilities of employees are becoming more and more important in corporate investment decision-making. This is because of the fact that service industries are now overtaking the manufacturing industries and in service providing business, the knowledge and intellectual competences of employees matter more than any other tangible asset.

Rahaman, Hossain and Akterl (2013) gave more specific definition of HRA, which refers HRA as the process of measuring the cost incurred by business firms and other organizations to recruit, select, hire, train and develop human asset. This definition gives a view as to what expenditure on the human resources should be recognized for valuation and reporting purposes. In other words, HRA involves the measurement of economic value of people to organizations.

\subsection{Issues in Human Resource Accounting}

One of the unresolved issues in Human Resource Accounting is the valuation model/methods of Human Resource available in organizations which has been regarded as the most valuable assets in business organizations. The professional Accountants, the Accounting Institutes and other stakeholders have not been able to agree on the financial value of human beings working in various organizations. The accountants and economists all over the world became conscious of the fact that appropriate methodology and procedures have to be developed for finding the cost and value of the people to the organization. Marharshi (2004)said that over a period of three decades, a number of experts have worked on it and produced certain models for evaluating human resources. Notable ones among them cited in Oluwatoyin (2014) are: (Shultz, 1960: William; 1967) Flamholz; 1971, 1972 \& 1975, Morese, 1973; Lav \& Schwartz, 1971; Jaggi and Lau 1974; \& Kenneth, 1978), etc.

Oluwatoyin (2014) identified two approaches to human resources accounting. These are:

Cost or historical cost approach and Value approach. Under human resource cost accounting method or model there are: (i) Acquisition cost model/Historical cost model, (ii) Replacement cost model (iii) Opportunity cost approach, (iv) Standard cost approach, while under the value approach method they are: (i) Present value of future earnings method, (ii) Reward valuation model (iii) Net benefit model (iv) Certainty equivalent net benefit model.

Each of the models/methods has its strengths and weaknesses and therefore could not meet the generally acceptable standard practice. The approaches are not without merit and demerits which render them unacceptable. The critiques are that it takes into account only a part of acquisition cost of employee, and it does not consider the aggregate value of their potential services (historical cost). 
Impossible to ascertain correct replacement cost of existing human resources since there can be complete replacements for them (Replacement cost). The total valuation of human resources based on this method may be misleading and in accurate (opportunity cost). It ignores the possibility that an individual may leave the organization for reason other than death or retirement, that is overstates an employee's expected service life and his future earnings (present value and reward valuation approach).

Another fundamental issue in Human Resources Accounting is the Measurement Models. Human beings are the dynamic elements of every organization. The success of any organization, to a great extent, depends upon the quality and caliber of the people working in it. In other words, human resources are the most important asset of an organization. Thus, in spite of all technological developments, the importance of human resources has in no way diminished. With the advent of scientific management, which emphasis on quantitative methodology to make a most efficient use of all resources, also it includes the computation of the human resource capital (Ratti, 2012).

In the progression of Human Resource Accounting, researchers have centered on the theoretical aspects ingrained in calculating the worth of human resources. HRA can be calculated pertaining to human resource outlay or according to human resource worth (Charian \&Faroug, 2013). In accordance to Flamholtz's (1999) method for the calculation of fundamental human resource outlay, human resource outlay could be described as two main classifications acquisition costs and learning costs where acquisition costs comprises of direct expenses of staffing such as enrolment, choosing, appointment and assignment, and indirect expenses of promotion or hiring from inside the establishment. Learning costs comprises of direct costs like official training and guidance and on-the-job instruction. In a HRA structure, acquisition and learning costs are considered as benefit accounts. with assures fiscal advantages in the years to, hence are not seen as expenditures (Charian \&Faroug, 2013).

The Stochastic Rewards Valuation Model, initially formatted by Flamholtz (1971) for human resource assessment, and described in more detail in Flamholtz (1999), consists of a five stage procedure that starts with describing the different service or institutional posts that a person could hold in the establishment. The following stage is to decide the worth of every post to the establishment, the service state values that could be measured by utilizing several means like the price-quantity approach or income approach.

Further, the individual's anticipated stay in service in the establishment is another issue affecting HRA. This is a measure of and the personnel's mobility likelihood or the likelihood of the individual holding every probable position in the specific years to come is calculated from archival statistics. After that, the anticipated cash flows in the years to come, that the individual produces are marked down so as to decide their current worth. As per Flamholtz (1999), one can note a dual characteristic to a person's worth. Initially, the individual's "anticipated conditional value," is the extent the establishment can possibly attain from their employment if the individual retains institutional membership all through the time of their useful employment tenure. Secondly, the individual's "anticipated realizable value." is the quantity really anticipated to be obtained, considering the individual's probability of turnover.

Charian and Faroug, (2013) suggested a different means for calculating intangibles termed "Intangible Assets Monitor." The 'intangible assets monitor' recommends a method for calculating intangible resources like the capability of a staff member, in-house composition like patents and patterns, and the exterior composition of the establishment like correlation with consumers and the like. This method incorporates pointers of development and restitution, and pointers of competence and constancy.

However, utilizing Flamholtz method, Flamholtz, Bullen and Hua (2003) revealed a convenient methodology for measuring return on Investment (ROI) on management advancement and revealed the increased funds flows that an establishment will get owing to investing in management advancement. The literature summarized that employing Human Resource Accounting as an instrument to calculate the worth of management development improves the worth of human resource capital and enhances the value of management accounting. Parallel to Flamholtz's method, yet another previous method of human resource value assesses human resource by measuring the current worth of an individual's earning capacity in the years to come (Lev \& Schwartz, (1971).

Dobija (1998) suggests a different method for capitalization, wherein the proportion of capitalization is decided with the help of natural and the societal circumstances of the surroundings. Employing a multifaceted interest attitude, this methodology considers three features for valuing the human resource personified in an individual. These comprise of capitalized value of living expenses, the capitalized value of educational expenses to get professional qualifications and the value attained with experience. Turner (1996) puts forward a different theory, where he points out to the structure released by the International Accounting Standards Committee and suggests the utilization, the current value of the value added by enterprise, and calculates resources by the four methodologies, such as historical outlay, present outlay, realizable worth and current worth.

Cascio (1998) suggested a methodology for calculating human resource on the basis of pointers of human resource of innovation, personnel attitudes and the record of wellinformed staff members. As per this methodology, modernization decrees a premium and thus requires to be calculated, for instance, by contrasting gross profit margins from latest goods to the profit margins from existing goods. Staff approaches envisaging consumer contentment and retention are significant pointers of human resources and consequently require to be calculated, in addition to measures of term, proceeds, experience and learning.

One explanation pertaining to the part of Human Resource Accounting suggested by investigators is connecting HRA to 
the Balanced Scorecard, (Johanson \& Mabon, 1998). Balanced Scorecard is an approach to management that integrates both financial and nonfinancial performance measurement in a framework proposed by Professors Kaplan and Norton. The BSC was first reported in the Harvard Business Review in 1992 and has since been adopted by a wide range of organizations. It is considered one of the most significant recent developments in management accounting. The approach looks at performance from four interrelated dimensions (Kaplan \& Norton 1996):

(i) The Financial Perspective: how do we measure financial performance? Possible performance measures include operating profits, return on capital employed, and unit costs.

(ii) The Customer Perspective: how do we measure customer satisfaction? Possible performance measures include customer profitability, customer satisfaction, and market share.

(iii) The Internal Business-Process Perspective: what must we excel at? Possible measures include time to develop new products, defect rates, and product returns.

(iv) The Learning and Growth Perspective: how can we continue to improve and create value? Possible measures include employee satisfaction and employee productivity.

The balanced scorecard approach requires managers to identify both lagging and leading measures. Lagging measures are financial measures that show the impact of decisions made in the past, whereas leading measures are non-financial measures relating to the customer, internal business process, and learning and growth perspectives. The latter are the drivers of future financial performance (Kaplan \& Norton, 1996).

By connecting the two, HRA will be grounded on business approach and the Balanced Scorecard can utilize the means that were formatted by HRA. A symbolic correlation between the two features would offer the needed recognition to HRA in business planning and the Balanced Scorecard will be extremely competent when it utilizes the weathered methods formulated by Human Resource Accounting.

Although investigators happen to accept the notion of connecting the two theoretically, there is difference of opinion on the means that could be utilized to attain this. Flamholtz (1999) suggest a different approach for grounding HRA in business policies. As per this method, one can note six important features of institutional functioning, comprising of markets, goods, assets, functioning structure, management structure and tradition. Yet another crucial feature comprises of fiscal outcomes of an establishment.

Generally, one can note seven aspects or important outcome fields that require being observed and kept in control by the administration of the establishment. Measurement is a vital element of control and HRA might hence be a helpful instrument for assessing human capital that consequently will be of use to the establishment, for efficiently controlling and managing human capital.
Lev (2001) in his ground-breaking book, 'Intangibles', talks about human capital as being one amongst several intangibles, that maybe the most difficult to calculate. Intangibles frequently have constructive response impacts, that is, employing them in one field could in reality augment benefits in another area. This is termed as the network advantages. For instance, the personnel who currently get training may eventually train others. Nevertheless, the worth of intangibles is common and human capital in specific is hard to calculate owing to difficulty in being purchased and sold and the absence of control over advantages in the years to come.

The personnel oriented by one firm might eventually seek employment in another firm. In the event of this taking place the value generated by orienting the employee is not attained totally by the first firm that trains the employee. The value "spills over", as it is termed, as the investment in training the employee goes to the second firm that employs him. The 'spill over' setback offers human resource managers with a distinctive chance to augment company value. If human resource strategies are built to decrease spill over, additional value from orientation is effectively held within the establishment. Effort should be taken to decrease spill over, this could take the strategy of particular instead of generalized training (Cherian \& Faroug, 2013).

Formulation of generally accepted human accounting standard is essential at this juncture. It may not represent the value of the HR as proposed in the historical cost based HRA, but the same cost elements may have to be recognized while judging the extent of the services, the employees render to the organization to reflect their value. The value assigned by organizations to their human resources just denotes the present value of the costs with respect to remaining service life of an employee in the organization rather than their contribution that it will receive from $\mathrm{HR}$.

It appears that the organization have stressed more upon the Human capital Accounting rather than Human Asset Accounting. The efforts made are to value human resources and to integrate and present their value in the conventional financial statements (Ratti, 2012). But, if the reality of HRA is to be derived, the concept of preparing financial statements has to be changed. Financial statements have to be prepared with a view which is based on human beings. Instead of the present view based on capital, the financial statements so prepared to show the human resources as assets to be termed as human based financial statements. Now, it is required under law for undertakings to maintain a separate item in their statement of financial position about such HR activities undertaken by them. So, organizations must implement HRA with vigor and clear directions. This is theoretical and not practicable at moment. The recently introduced International financial Reporting System (IFRS) did not recognize the concept of HRA reflecting/appearing in organization's statement of financial position as an asset.

It can be inferred that the value of human resources does not depend upon the number of human beings employed. The situation may be that value of human resources may be 
higher in spite of less number of human capitals. So, another factor that increases the value of human capital is amount paid by organizations to their employees. If companies pay higher amount on salaries to their human resources then value will be higher, and if companies will pay less, human capital will be low. This is why, companies have higher number of human resources but their value is less than the companies which employed less number of employees. If companies paid higher salaries to their employees, human capital worth is higher (Ratti, 2012).

Another major issue of HRA is the recording and disclosure of value of HR in the financial statement of organizations. The "present value of future earning" model, as suggested by Lav and Schwartz (1971), has been found to be most popular model on account of convenience and objectivity. The exponent of human resources valuation models in most cases have not dealt with the mode of recording and disclosure of the accounting information relating to human resources in the books of account or financial statements of the organization. This has been left to the discretion of the accounting bodies that are yet to develop a generally accepted basis for valuation, recording and disclosure of human resources accounting information in the financial statements of an organization. In most cases, the human resource accounting information is given in the form of supplementary information attached to the financial statements. This is of great concern to accounting professionals and practitioners.

Dasgupta (1978) has suggested in his total cost approach the following mode for disclosure of human resources in the statement of financial position of an organization. He said that the human resources valued as per his model should be shown both in the "asset" as well as "liabilities" sides of the statement of financial position. On the assets side, it should be shown after the fixed assets as Human Assets classified into two parts: Value of individuals and Value of organization's investment on the "liability" side. According to him, if human resources are accepted as assets they should be taken out of expenses items from the statement of comprehensive income (profit and loss account) and brought to the statement of financial position. It should be shown after the capital as Human Assets Capital by that amount at which it has been shown on the asset side against "value of individuals."

Furthermore, Wright (1970) posits that the following conditions must be present before adapting to Human Resource accounting in any organization:

1) Top management must be willing to adopt the human resource philosophy,

2) Organization must be willing to invest in money and time,

3) There must be people knowledgeable and willing to learn.

He contended that the notion of capitalizing investment in human resource will lead to a new way of thinking about managing man as capital. Thus, accounting treatment of investment made in man as assets rather than as expenses will invariably assume a better status as a result of management recognition of people (employees) truly as assets possessing future expected benefits which must be recorded and reported.

Financial reporting is a means through which information about the financial status of the company will be offered to shareholders, current and potential investors of company, creditors and other users. Currently, expenses related to Human Resources in financial accounting are considered as the period expenses that in the case of gains and losses will be deducted from the net profit of company. While these expenses are the assets of future benefits and should be proposed as assets in the statement of financial position of the company.

Although, there are several models for measuring the historical cost and value of human resources, human assets measuring are subjective and depend on personal thoughts in this method. One of the reasons is that the company is not the real owner of its manpower because there is the possibility of manpower changing during the company's activity. However, this problem is removed by estimating the possibility of employees' death and leaving in value-based models. However, the possibility to take advantage of these valuebased methods decrease since the financial statements are in accordance with the accepted accounting principles and are prepared based on the objective and historical data. The reason that the accepted accounting principles support the objectivity, reliability and impartiality as the qualitative characteristics of financial information is to enhance the comparability of financial reporting among the business units (Mahmoodi et al, 2013).

Appling the methods based on the estimation and personal judgment reduces the comparability of financial statements. Although using the cost expenses approach related to the human resources instead of its reflection as an asset increases the degree of objectivity and reliability of financial reporting, it may reduce the relevance of information for decision making. Therefore, it can be said that although HRA-based criteria involve the subjectivity in valuation, they are very concerned to the real needs of investors (Flamholtz, Bulen, \& Hua, 2003).

Many of the models discussed above use different inputs to value an employee. None of them are by any means all inclusive. It is important to examine factors that contribute to an employee's productivity. These factors fall into several different categories, each important in their own way (Stanko, Zeller, \& Melena, 2014).

Education is one important way to capture an employee's value. Education includes elements such as schooling, work training, external training, and certifications and degrees. The more schooling and training an employee has, the more likely they are to bring greater value to an organization. This is not always true as natural intelligence and other factors are also vital, but it is generally a good indication. Education is often represented in employee salaries, but should not always be. For this reason, it is critical that many factors be taken into consideration when determining the value that an 
employee brings to an organization and not just obvious factors such as salary or education.

Salary and other benefits also play an important role in determining employee value, especially in an approach that nets the employees value and costs associated. Salary and benefits are investments that are associated with the expected return of the employee. The greater the difference between the value and the cost is, the better the investment by the company. The same is true for recruiting and training costs associated with obtaining the employee in the first place. Employee value must be captured mainly through performance in their role. Although difficult, employee reviews by managers and other data; for example, sales numbers for a salesman or deliverables met for an IT professional, must be quantified and taken into account (Stanko, Zeller, \& Melena, 2014).

The natural attributes an employee has are also important. A good, charismatic speaker is likely to better sell ideas or products. A naturally intelligent person, whether they attended college or training class or not, can obviously still be of great value to a company if they are good at what they do. Certain attributes that are crucial to success in one industry can be of little help in another.

Job experience is also crucial to the value that an employee can provide the company. If an issue arises that an employee has previously experienced, they will be much more likely to resolve it in a timely, effective manner. Generally, the more time spent in a job or industry, the more knowledge and people that employee will gain and know. They are also able to impart their experience to other employees.

Relationships are crucial in any organization. For example, if an employee has a good relationship with an outside vendor, they will likely be able to get extra benefits from the vendor than a person with whom the vendor has no rapport. Relationships within the organization are also vital. If employees know each other and get along, they will be much more likely to work through a project efficiently and without issue. Employees that get along can keep morale high, which leads to a better work environment and greater productivity.

Time left with a company is also important, as seen by its inclusion in many models. If an employee is going to be capitalized as an asset, there must be a good idea of the "useful life" of the employee or for how much time they will remain with the company. Retirement, leave, and death are all reasons that must be taken into account. A similar application is how companies account for pension plans. All of these factors play a role in determining the actual value of an employee (Stanko, et al, 2014).

It has already been pointed out earlier that (i) social cost (ii) acquisition cost including costs of recruitment, hiring, selection and placement of employees, (iii) orientation and on-the-job training costs, including salaries paid to the employees during their probationary period, (iv) formal training development costs of employees, (v) separation costs of employees, (vi) costs incurred for gravid female employees, (vii) rewards for extra ordinary performances and academic attainments and (viii) extra ordinary health costs needed to be "assetized" since the benefits from them are expected to be derived for more than one year. To fulfill one vital accounting principle - "matching of costs and revenues" are required to "assetize" the eight categories of costs mentioned above. On the other hand, all the elements of "maintenance expenses" need to be treated as revenue expenses and charged to revenue accounts of the periods concerned.

\subsection{Benefits of Human Resource Accounting}

It is generally accepted that human resources are the most important to the success of every organization. However its inclusion in the statement of financial position of firms has been strongly denounced in certain quarters. It is interesting to note that all the valuation methods stated in this study have certain disadvantages or limitations; however, accounting for human resources can be a plus to the organization and its stakeholders. Craft and Bimberg, (1980); Ezeagba, (2013) despite their apprehension on Human Resource Accounting explained the benefits of HRA. Gogo itemized some of the benefits of HRA to include:

i. Proper integration of Return on Capital Employed (ROC E) in disclosure of the value of human resources in the longterm perspective of the business performance.

ii. The maintenance of detailed record relating to internal human resources will improve managerial decision-making process in Recruitment Vs Promotion, Transfer Vs Retention, Retrenchment Vs Retention.

iii. Help in efficient use of Human resources and allocation of resources in the economy.

iv. Help in proper understanding of the evil effects of avoidable labour unrest or disputes on the quality of internal human resources (Gogo, 1987).

Additionally, this study supports the view of Oluwatoyin (2014) who pointed out the need for Human resources accounting that provides useful information to the management, financial analysts and employees. as stated below:

i) Human resources accounting helps the management in employment and utilization of human resources.

ii) It helps in deciding transfers, promotion, training and retrenchment of human resources.

iii) It provides a basis for the planning of physical assets vis-à-vis human resources.

iv) It helps in evaluating the expenditure incurred for imparting further education and training of employees in terms of the benefit derived by the organization.

v) It helps to identify the causes of high labour turnover at various levels and making preventive measures to contain it.

vi) It helps in understanding and assessing the inner strength of an organization and helps the management to steer the company well through the most averse and unfavourable circumstances.

vii) It helps in locating the real cause of low returns on investment, like improper or underutilization of physical 
assets or human resources or both.

viii) It provides valuable information for persons interested in making long-term investments in the organization.

ix) It helps the employees in improving their performance and bargaining power. It makes each employee understand his contribution towards the betterment of the organization vis-à-vis the expenditure incurred by the organization on him.

These benefits are so enormous to be ignored in accounting practices. Consequently numerous investigations were centered on showcasing a connection between Human Resource Accounting methods and organization or company performance; to effectively examine the extent HRA has contributed to the profitability of firms (Afiouni, 2007; Johansson, 2007; Youndt \& Snell, 2004; and Cherian \& Farouq, 2013).

It was revealed that for high performing organizations in order to keep performing on a continuous basis must treat their human capital as the most important and valuable asset. They should treat them as adults, as partners and with dignity and respect. Since 'People who feel good about themselves produce good results' and 'People who produce good results feel good about themselves'. Such a healthy and virtuous cycle goes on and on, satisfying the individual goals and organizational goals too at the same time, in that the individual drives the job satisfaction, which in turn induces him to reach out for excellence, culminating in the all round development of the performing organizations.

Furthermore, there is the Need for Human Resources accounting to the Organization. Human Resources accounting is intended primarily to be used as a management tool, it has significant uses for present and potential investors and other users of financial statement. Oluwatoyin, (2014) has the following as needs and uses of Human Resources Accounting for internal and external purposes; For internal purposes the human resources data as part of the management information system helps in making meaningful choice between various types of human investment and investments in other assets. The HRA provides information of vital importance for short term and long term decision making as well as performance measurement. Also Human resource valuation provides the management with information about change in the structure of its labour force.

For the external purposes, the value of organization's human resources is helpful to prospective investors and other users in making long term investment decisions. It provides the organization with a more accurate accounting of its return on the total (financial, physical and human) resources employed. The rate of return calculated in this manner will be more realistic. Those interested in making long-term investment decision in an organization will be interested in having an insight into its inner strength. It provides useful information to the management, financial analysts and employees as stated according to expert that worked on human resources accounting (Oluwatoyin, 2014).

\subsection{Challenges and Obstacles of Human Resources Accounting to Organizations and HR Professionals}

It is evident that organizations face several challenges during the HRA implementation. A case study of an Australian bank's human capital disclosures was provided by Dumay and Lu (2010). It describes the investigation of such exposed disclosure by both external and internal stakeholders. They said that the adversarial stakeholders can question the organization or even change the management and disrupt the balance between staffs and management if the organization fails to implement the rhetoric obtained from the disclosures. In November 2005, based on the repealing of human capital law, Roslender and Stevenson (2009) state "genuinely shocked interested parties and led to widespread criticism." As a result, these disclosures placate the individuals from accounting profession, especially the auditors (Roslender \& Stevenson, 2009). The studies by Foong, Yorston and Gratton (2003) describe the rationale for resisting these disclosures by entrepreneurs.

The disclosure of HR information may act as a proof for wealth creation and hence this may result in increased bargaining power for both unions and employees. The critical accounting theory supports these findings. According to critical accounting theory, accounting numbers quantify the events and are used to subjugate the labour by the firm owners. A survey was conducted by Verma and Dewe (2008) to recognize and explain the perceptions of human resources and their practices in different organizations and sectors. A number of respondents considered the human resources measurement as vital to the organization. However, it was expected that a little or considerable improvement will occur in the measurement practices of human resources in the upcoming years. This is due to the following reasons: uncertainties in the reporting areas; sensitivities in the reporting areas; less accuracy in present measurement techniques and lack of organizational support.

However, several HR personnel are not considering human capital as a fundamental element of intellectual capital. Lawler (2009) stated that "unlike experts in finance and experts in accounting, experts in HR typically are not on company boards". As per Sarbanes-Oxley Act (2002), every publicly listed organization should have a qualified, financially experienced board member. However, the HR department does not have any such standards. This clearly reveals that organizations face several challenges during the implementation of HRA.

Although, the theory of HRA appears to be useful, there is still lack of adequate standards for the valuation of HR. The mere process of putting number to things can easily be taken outside the context of their proper use. It is likely that managers will treat human quantitative data not different from quantitative data regarding the physical plant and machinery.

The managers may use HRA as a means of manipulating the employee. She/he may decrease the value of an employee as a form of punishment or control. This may be done by 
altering the variables like the probability of an employee being promoted to the next state, future increments etc., determining the value of HR. The employee's bargaining power might be increased if his/her value was known. However, power might be increased if his/her value was known (Ratti, 2012).

Oluwatoyin, (2014) states that there are many obstacles which make the management reluctant to introduce human resources accounting. He outlined some of the attributes to include:

(i) There is no proper clear cut and specific procedure or guideline for finding cost and value of human resources of an organization. The systems which are being adopted have certain drawbacks.

(ii) The period of existence of human resource is uncertain and hence valuing them under uncertainty in future seems to be unrealistic.

(iii) The much needed empirical evidence is yet to be found to support the hypothesis that human resources accounting as a tool of management facilitates better and effective management of human resources.

(iv) As human resources are incapable of being owned, retained, and utilized, unlike the physical assets, there is a problem for the management to treat them as assets in the strict sense.

(v) There is a constant fear of opposition from the trade unions as placing a value on employees would make them claim rewards and compensations based on such valuations.

(vi) In spite of all its significance and necessity, the tax laws don't recognize human beings as assets.

(vii) There is no universally accepted method of the valuation of human resources.

From another perspective, Jasrotia (2004) looked at the trends in the field of HRA and came up with some factors that deter the progress in the area and the application of the concept. The following are some of the problems the researcher uncovered.

i. Awareness and Acceptance: The level of awareness and acceptance of HRA is still low as many companies take little imitative to make the information available to the shareholders despite having the data.

ii. Lack of an Industry Standard: The absence of an industry means that every company has to evolve its own standard, which can become a tedious process considering that most of them are still involved in improving their business.

iii. Extensiveness of the Research Involved: Another aspect working against the acceptance of HRA is the need for extensive research that it entails. Many companies do not want to go into the intricacies of finding the value of their human resources. While it may be affordable for most big companies to dwell into such best practices, it is likely not going to be an economically viable option for small and medium size companies.

iv. Dynamism of Some Industries: certain industries, like the information technology, are very dynamic due to frequent discoveries and technological advancement. In these types of industries, it is very difficult to predict as to what is going to be future requirements and how technology is going to shape in the near future.

On another perspective, human resources, according to Roslender (2004), have some special attributes, which in turn make their valuation so peculiar. These attributes include the following:

a) Uncertainty of the Service Period: Whereas the service period of the conventional assets like fixed assets can be estimated with some degree of certainty, the human assets service period is too uncertain. This is because of the free mobility of recruits/employees whenever they so desire. An employee can leave a job for another one at anytime without notice; since he knows the usual thing is just to return some few months' basic salary to his employer.

b) Uncertainty of the contribution Level of Recruits: The estimation of an employee's contribution level to the organization is very uncertain. Quite unlike a machine installed by a company, that can have a definite production capacity level. This makes estimation and forecast very easy and reliable. It is very certain that an employee's contribution level is too difficult to be estimated and forecasted with much reliability. His/her productivity fluctuates and depends on many other factors.

c) External Factors Influence on the Employee Future Reward: In valuing human resources, the payments in terms of salaries and/or wages count a lot. An employee that is very valued in terms of the future salaries and wages determined today would have his value affected whenever the government changes policy affecting his reward system or whenever there is an action from the workers union regarding the reward system.

\section{Conclusion and Recommendations}

The exponent of human resources valuation models in most cases have not dealt with the mode of recording and disclosure of the accounting information relating to human resources in the books of account or financial statements of the organization. This has been left to the discretion of the accounting bodies that are yet to develop a generally accepted basis for valuation, recording and disclosure of human resources accounting information in the financial statements of an organization. In most cases, the human resource accounting information is given in the form of supplementary information attached to the financial statements. This is of great concern to accounting professionals and practitioners.

The paper concludes that considerable research done is due to the increasing importance of human capital in the economy to develop the concepts and methods of valuing human resource that has been recognized as human resources accounting (HRA), and that there is a great need for evolving a system of accounting for human resource that is acceptable to professional accountants, mangers and other decision makers - investors, creditors and other stakeholders.

The study recommends that standard of HRA valuation 
should be created for human resource identification and measurement. This will enhance valuation of human capital, ensure a higher degree of utility to stakeholders, uniformity in disclosures and allow a reliable comparison of human capital values. There should be a regulation in the accounting standard setting process for human capital reporting and Proper techniques should be developed for valuation of human resources and generally acceptable formats should also be evolved by the accountants for disclosure of this vital information in the financial statement of firms.

\section{References}

[1] Afiouni, F. (2007). Human resource management and knowledge management: a road map toward improving organizational performance. Journal of American Academy of Business, 11(2), 124-31.

[2] American Accounting Association (1973), "Report of the committee on accounting for human resources." The Accounting Review, 48, pp. 6-11.

[3] Cascio, W. F. (1998). The future world of work: Implications for human resources costing and accounting. Journal of human resource costing and accounting, 3(2), 919,http://dx.doi.org/10.1108/eb029045.

[4] Cherian, J. \& Farouq, S. (2013).Review of human resource accounting and organizational performance; International Journal of Economics and Finance; Vol. 5, No. 8; 2013 Retrieved on April 23 2016, from URL: http://dx.doi.org/10.5539/ijef.v5n8p74.

[5] Craft, J. \& Bimberg, L. (1980). Human resources accounting: Perspective and prospects management. A book of readings. Harold Knoontz and Cyril O. Daniel. McGraw Hill, USA.

[6] Das-Gupta, N. (1978) Human resource accounting; New Delhi, Sultan Chand \& Sons.

[7] Dobija, M. (1998). How to place human resources into the balance sheet. Journal ofHumanResource Costing and Accounting, 3(1), 83-92. http://dx.doi.org/10.1108/eb029044.

[8] Dumay, J., \& Lu, J. (2010). Disclosing improvements in human capital: Comparing results to the rhetoric. Journal of human resource costing \& accounting, 14(1),7097.http://dx.doi.org/10.1108/14013381011039807.

[9] Ezeagba, C. E. (2013). The need for inclusion of human resources accounting in the balances heet. African Research Review, an International Multidisciplinary Journal, Ethiopia. Vol. 8(2) serial No. 33.

[10] Flamholtz, E. G. (1999). Current issues, recent advancements, and future directions in human resource accounting. Journal of human resource costing and accounting, 4(1), 11-20.

[11] International Accounting Standards Board. (2009). Retrieved on April 28, 2016. From www. iasb.org.

[12] Flamholtz, E. G., Bullen, M. L., \& Hua, W. (2003). Measuring the ROI of management development: An application of the stochastic rewards valuation model. Journal of Human Resource Costing and Accounting, 7(1-2), 21-40. http://dx.doi.org/10.1108/eb029077.

[13] Flamholtz, E. G. (1971). A model for human resource valuation: A stochastic process with service rewards. The Accounting Review, 253-67.

[14] Flamholtz, E. G. (1987). Human resource accounting: Measuring positional replacement costs human resource management, $8-16$. http://dx.doi.org/10.1002/hrm.3930120103.

[15] Flamholtz, E. G. (1999). Human resource accounting: Advances, concepts, method sand applications. Boston, MA: Kluwer Academic Publishers. http://dx.doi.org/10.1007/978$1-4615-6399-0$

[16] Foong, K., Yorston, R., \& Gratton, L. (2003). Human capital measurement and performance: a British perspective. Retrieved from http://www.accountingforpeople.gov.uk.

[17] Friedman, A. \& Lev, B. (1974), "A Surrogate measure of the Firm's investment in human resources." Journal of Accounting Research, No. 12, pp. 235-250.

[18] Gogo, S. F. (1987). Accounting for human resources; The Nigerian Accountant; (July/Sept) Vol. 20 No3.

[19] Gupta, D. K. (1991), "Human resource accounting in India: A perspective." Administrative Staff College of India Journal of Management, Vol. 20, No. 1, pp. 9-10.

[20] Jasrotia, P. (2004). The need for human resource accounting, Retrieved on April

14,2016fromhttp://www.itpeopleindia.com/20021216/cover.s html.

[21] Johanson, U., \& Mabon, H. (1998). The personnel economics institute after ten years: What has been achieved and where we are we going? Journal of Human Resource Costing and Accounting, 3(2), 65-76. http://dx.doi.org/10.1108/eb029049.

[22] Johansson, J. (2007). Sell-side analysts' creation of value key roles and relational capital.

[23] Journal of HRCA: Human Resource Costing and Accounting, 11(1), 30-52. http://dx.doi.org/10.1108/14013380710746393.

[24] Kaplan, R. \& Norton, D. (1996). Using balance score card as a strategic management system Harvard business Review Journal, February, Pp 3- 13.

[25] Lau, A. H. \& Lau, H. S. (1978), "Some proposed approaches for writing off capitalized Human Resource Assets". Journal of Accounting Research, No.16, pp. 80-102.

[26] Lawler, E. E. (2009). Make human capital a source of competitive advantage. Organizational Dynamics, 38(1), 1-7. http://dx.doi.org/10.1016/j.orgdyn.2008.10.007.

[27] Lev, B. (2001). Intangibles: Management, measurement and reporting. Brookings Institution Press.

[28] Lev, B., \& Schwartz, A. (1971). On the use of the economic concept of human capital in financial statements. Accounting Review, 103-112.

[29] Mahmoodi, P., Babae, F. \& Mohamade, J.(2013) Human resources accounting: from theory to practice. European online journal of Natural and social science Europeans, Vol. 2No.3(s) Available at www.eruopean.science.com retrieved on May 15, 2016. 
[30] Micah, L. C., Ofurum, O. O. \& Ihendinhu, J. U. ( 2012) Firms financial performance and human resources accounting disclosure in Nigeria; International Journal of Business and Management; Vol. 7 No. 14 Available at www.ccsenet.org/ijbm Assessed on 12/4/2016.

[31] Newman, B. H. (1999). Accounting recognition of human capital assets. New York: Pace University Press.

[32] Okwy P. O. \& Christopher C. O. (2010). Human capital accounting and its relevance to stock investment Decisions in Nigeria. European Journal of Economics, Finance and Administrative Sciences, 21, 64-76.

[33] Oluwatoyin, A. S. (2014) Human resources and accounting and disclosure in financial statement: literature Review. Research Journal of Finance and Accounting, Vol.5 No 22 Available at www.iiste.org. Retrieved on May 10, 2016.

[34] Rahaman, M., Hossain, A. \& Akter, T. 2013). Problem with human resource accounting and possible solution. Research Journal of Finance and accounting; available atwww.iiste.org retrieved on June 15, 2015.

[35] Ratti, M. (2012). An Analytical study of human resource accounting practices - An Indian experience. Integral Review - Journal of Management, Vol.5 No 2.pp 37-45 Available at http// www.integraluniversity.ac.in/net/journals. Retrieved on March, 12, 2016.
[36] Roslender, R. (2004). The prospects for satisfactorily measuring and reporting intangibles: Time to embrace a new model of accounting? Journal of Human Resource Costing and Accounting, 13(4), 338-359. http://dx.doi.org/10.1108/14013381011010169.

[37] Roslender, R., \& Stevenson, J. (2009). Accounting for people: A real step forward or more a case of wishing and hoping? Critical perspectives on accounting, 20(7), 55-69. http://dx.doi.org/10.1016/j.cpa.2007.02.003.

[38] Stanko, B. B, Zeller, T. \& Melena, M. F. (2014). Human asset accounting: moving forward; Journal of Business and Economics Research-Second quarter, 2014 Vol. 12, No. 2 Pp 93-104.

[39] Verma, S., \& Dewe, P. (2008). Valuing human resources: Perceptions and practices in UK Organizations. Journal of human resource costing and accounting12 (2), 102-123. http://dx.doi.org/10.1108/14013380810889547.

[40] Wright, R. (1970) "Managing man as capital assets" Personal journal. Available atwww.ijste.org. Retrieved on April 15, 2015.

[41] Youndt, M. A., \& Snell, S. (2004). Human resource configurations, intellectual capital and organizational performance. Journal of Management Issues, 16(3), 337-60. 